\title{
Development of Expert System by using Logical Comparative Conclusion in the Function of Organizational Performance Improvement
}

\author{
Aleksandar VUJOVIC, Zdravko KRIVOKAPIC, Miladin STEFANOVIC, Jelena JOVANOVIC
}

\begin{abstract}
The paper is created as the tendency of a group of authors, that with an integrative approach in the application of intelligent systems, by using analogy with some function in human body, to develop a model to improve organizational performance. The paper is based on two unique bases, of a representative number of data that reflect real business conditions and including a significant number of organizations. In order to achieve the set goals, several approaches were adopted, tools and methods, such as analytic hierarchy process (AHP) methodology, case base reasoning, artificial intelligence tools- expert systems, verification in real condition and other. As the key outcomes of the paper are obtained the fields that are critical to achieve the best organizational performance, and indicators for the development of expert systems whose functions, efficiency and effectiveness are verified in real conditions.
\end{abstract}

Keywords: AHP methodology; artificial intelligence; expert systems; organizational performance

\section{INTRODUCTION}

Application of artificial intelligence (AI) tools, among other things, in the function of obtaining competitive knowledge, in the function of automation and development of decision support systems, represents an imperative in today's business environment, globally oriented economy and science. Therefore, any research that is based on a unique approach with results that have been verified and validated in real-world conditions, should be an incentive to researchers and timeliness of such research is unquestionable.

Continuous improvement of organizational performance is the priority of any successful business system, and the urgent need to ensure sustainability in the global market. One of the bases for improving organizational performance is the application of the internationally accepted standard, even that of series ISO 9000. Research in the field of management systems, but also in quality management systems (QMS), individually or in an integrated approach, they have to move in the direction of securing conditions for benefits for the organization, up to those of financial character. This includes the provision of a system of continuous improvement, organizational sustainability and competitiveness. Such a reality, or rather inevitable, provide an incentive to authors of this paper that with the application of intelligent approaches and models in the field of QMS, to come to a unified approach to improve organizational performance, as well as the efficiency and effectiveness of all processes in the organization.

The paper consists of an introductory part in which two subject fields, the AI and the QMS have been selected. In the second part of the paper, literary sources have been analyzed, indicating the main trends in the subject fields studied. Moreover, the scientific methods applied in the paper and the stated goals have been thoroughly presented in this section. The third part of the paper is devoted to experimental research with an indication of data sources, uniqueness and significance of databases. In this section we pointed out the approach used to develop an expert system. In the fourth part of the paper, the calculation of the necessary indicators for the expert system was carried out, through the application of the selected methods. The development of the expert system and the verification of the results are presented in the fifth part of the paper. The final considerations are presented in the last section.

\section{ANALYSIS OF THE RESEARCH IN SUBJECT FIELDS, METHODS AND OBJECTIVES OF THE PAPER}

In the field of improving the process, or organizational performance, and based on the QMS, analysis of the use of tools, methods, and techniques are moving towards the usage of traditional approaches of the type of SixSigma, FMEA, Taguchi, etc. In this sense, there is a lack of research dealing with the application of AI, in terms of data collection, analysis and application of knowledge in the function of improving organizational performance $[1,2]$. Some developed systems for support of decision-making have partial character and relate only to the particular fields of the organization, or the standard for quality management systems, such as the satisfaction of the user, the field of reclamation and fulfillment of the objectives, which essentially is not enough and does not encompass the entire system [3-8]. In addition, most of the research in the field of intelligent systems, and thus the system of artificial intelligence refers to the manufacturing organization, with a clear differentiation of the organization of the second type.

It certainly does not support the generic understanding of the product, based on European Standards after which the product is defined equally in four categories such as process products, services, hardware and software $[9,10]$. Some studies regarding the application of intelligent systems, also by selective approach, are moving in the direction of creating business processes based on social responsibility and only partly take into account the sustainability of the organization and improve its processes [11], although a significant number of literature sources, speaks about the necessity of research in that direction [12, 13].

Also, many literature sources indicate that the organizations that operate in the global market, there is a lack of knowledge or lack of tools to develop expertise for 
organizational improvement, which also supports the fact of the necessity and actuality of research in the field of artificial intelligence, for the purpose of obtaining competitive knowledge [14]. The significance of the research in the field of artificial intelligence from the point of gathering and analysis of data, the clear function and activity of the growing number of experts in the field of data analysis unquestionably indicates the importance, timeliness, and the necessity of research and subject fields [15].

In this way are going and conclusions mostly on the increasing role of science and scientists in the functions of data analysis and knowledge achievement [16]. The role of the user in the process of improving business processes, through access to the results and at the level of fulfillment of organizational goals, and by using AI is a necessity for socially responsible and sustainable systems $[17,18]$. Certainly, for the purposes of applying modern information systems and tools to improve the function of organizational data, you need to provide representative input parameters or data that output or representation of knowledge was adequate, but implemented and integrated development models of intelligent systems for automation of traditional approaches [19, 20]. In fact, the development and successful application of modern management information systems, with a clear link to performance data processes can be achieved using modern decision support systems as a component of a modern information system [21-24].

In addition, considerable research suggests improving organizational performance administration may occur by using Case-Based Reasoning approach (CBR), as an excellent model for obtaining inputs for some of the tools of artificial intelligence and the development of new intelligent approach $[25,26]$.

Another field that is being research in the paper is the QMS, which affect organizational performance, is undoubtedly, with the condition that it is established in compliance with the basic principles of continuous improvement $[27,28]$. That means the introduction of the world's best practice and best organizations practice [29, 30]. Studies show an increase in the number of certificates on an annual level of around $4 \%$ for the reason that this system affects the increase in sales and financial growth of the company, so every improvement in this system has a direct impact on improving financial gain for the organization [31-35].

Reasons for certification of management systems standards are different, but certainly among the most significant achievement of the marketing advantages, increase innovation, an increase of sales and productivity, improve employee satisfactions, etc. [36-40]. Benefits from the implementation of the standard are also visible through the improvement of the absolute pleasures of stakeholders and management system to supply, as a key factor for organizational sustainability $[41,42]$. In relation to the environment and very dynamic variables of the global market, the new version of the standard from 2015, certainly make a profit and provide organizational adaptation $[43,44]$.

The organizational culture of quality improvement that enhances the introduction and certification of management systems standards, contributes to improving organizational performance through responsible and effective attitude towards the employees and management activities for which they are responsible $[45,46]$. From the point of growing trends in terms of corporate social responsibility and to meet environmental requirements when designing new products, certification of quality management system has a positive impact which is also very important gain for the organization [47].

This system also has an effect on organizational performance, especially if it is established in integrated form with other management standards, like environmental management systems, occupational health and safety assessment, etc. [48, 49]. The entrepreneurial character of the organization and employees, as well as respect for the principles of leadership, are one of the key aspects that are developed using standard norms of quality management system [50].

Such defined trends in research of subject fields, justify the tendency of authors to develop a modern approach to the acquisition and representation of knowledge in order of continual business improvements. In the paper primarily were using scientific research methods of inductive and deductive reasoning. In addition to these, in the paper were applied and other methods, tools, and approaches, such as decision-making on the basis of previously established facts or experiences, methods of analogy or logical comparative reasoning, expert systems and multiple criteria decision making method.

Based on the previous expressed, the basic objectives of the operation were defined, such as:

- Identify the most important areas to improve organizational performance, based on quality management system in order to develop an expert system, as well as decision support systems.

- Based on pre-defined objectives or indicators of the primary areas to improve organizational performance, develop the intelligent system as a system for decision support in order to achieve greater competitiveness and sustainability of the company.

\section{EXPERIMENTAL RESEARCHES AND DEVELOPMENT OF INTEGRATED APPROACH FOR THE DEVELOPMENT OF EXPERT SYSTEMS}

The basis of the paper consists of research conducted in a significant number of organizations that are certified according to ISO $9001 \mathrm{model}$ and/or participated in the contest for awards for business excellence by the European Quality Award model or are winners of these awards. In this sense were formed two single databases, as follows:

1. Database of non-compliance (the first level of data), which were identified during external testing in 453 organizations with 1630 non-compliance in total.

2. Database of experiences from the evaluation of organizations that participated in the contests to obtain awards for business excellence by the European model (the second level of data). This database indicates the occurrence of non-compliance in the 68 organizations.

These databases are unique and in order to ensure integrity of the firms, the data are stored in coded form.

The data represent the long-term experience of successful certified organizations, as well as the best ones, thus in terms of application the access CBR, which is 
applied in this paper, lead us to adequate conclusions. The second level of data is used for comparison with the first level, in order to obtain results and conclusions about the best organizational performances and priority areas and activities for improvement. Accordingly, the necessary indicators for the expert system building are obtained. Based on an approach to intelligent bionic systems, was established an analogy process-based business system with the so-called, involuntary functions of the human organism. Precisely this analogy is possible, bearing in mind the action, the role and importance of involuntary functions on the one hand and the experimentally obtained two types of data.

These are functions that do not depend on the human will and one can easily perform and there are naturally healthy and fully functional organisms. For example, it functions as hormone secretion, or an enzyme, and the like $[51,52]$. Exactly such established analogy provides the ability to obtain conclusions for all types of organizations, regardless of their size or field that they deal with.

\section{CALCULATION OF INDICATORS FOR THE NEEDS OF EXPERT SYSTEM DEVELOPMENT}

Based on the predefined approaches, and in order to obtain the results and establish a relation between the first and second data level, or indicator for the development of an expert system, has been introduced a depending variable $R$, which is called the "Degree of readiness" for the purposes of achieving business excellence.

This variable refers to organizations of any size and type and is calculated individually for each application standard ISO 9001, by using next formula:

$R=N_{Z i} \cdot S_{Z i} ; i=1,2, \ldots, 28$

Where $N_{Z i}(\%)$ is the variable that is expressed depending on the number of non- compliance and represents a socalled the force of the standard field and $S_{Z i}$ is coefficient of significance for achieving business excellence. For the calculation of the $R$ variable is established a model shown in Fig. 1.

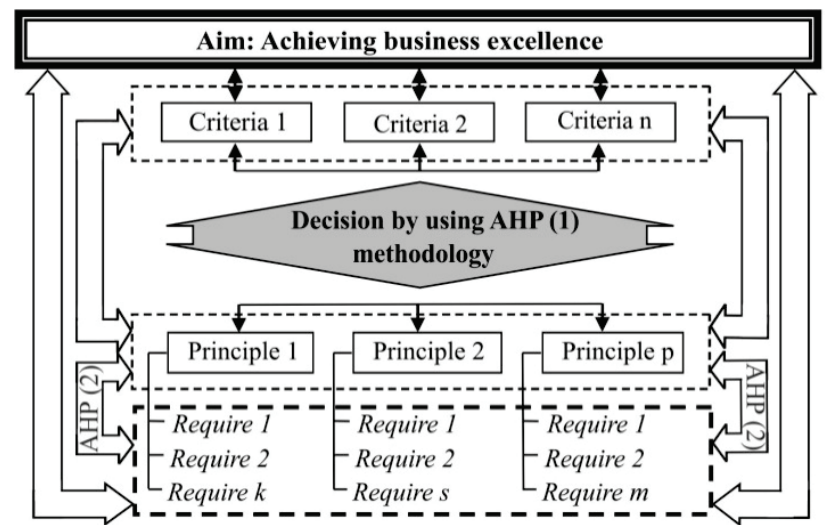

Figure 1 Application of AHP methodology for establishing relations between areas of standard and business excellence

According to this model, were conducted two AHP sub-models, as follow:
- AHP 1model for the establishment of relations between the principles of standard series ISO 9000 and the main objective,

- AHP 2model in order to find connection among the fields of standards and the main goal or achieving business excellence, based on the results of the AHP1 model.

Based on this approach, results were obtained (Tab. 1).

Table 1 The values of the parameters for the expert system development

\begin{tabular}{|c|c|c|c|c|}
\hline & Requests & $\begin{array}{l}\text { Organization } \\
\text { (strength) }\end{array}$ & $S_{Z}$ & $R$ \\
\hline \multirow{4}{*}{$\begin{array}{c}\text { Module } \\
4\end{array}$} & 41 & 30,98 & 0,023 & 0,71254 \\
\hline & 42 & 35,96 & 0,001 & 0,03596 \\
\hline & 43 & 34,24 & 0,015 & 0,5136 \\
\hline & 44 & 19,3 & 0,001 & 0,0193 \\
\hline \multirow{3}{*}{$\begin{array}{c}\text { Module } \\
5\end{array}$} & 51 & 83,25 & 0,053 & 4,41225 \\
\hline & 52 & 70 & 0,054 & 3,78 \\
\hline & 53 & 35,68 & 0,03 & 1,0704 \\
\hline \multirow{3}{*}{$\begin{array}{l}\text { Module } \\
6\end{array}$} & 61 & 23,81 & 0,045 & 1,07145 \\
\hline & 62 & 45,12 & 0,01 & 0,4512 \\
\hline & 63 & 23,34 & 0,007 & 0,16338 \\
\hline \multirow{5}{*}{$\begin{array}{c}\text { Module } \\
7\end{array}$} & 71 & 61,17 & 0,064 & 3,91488 \\
\hline & 72 & 20,06 & 0,008 & 0,16048 \\
\hline & 73 & 54,28 & 0,041 & 2,22548 \\
\hline & 74 & 39,07 & 0,056 & 2,18792 \\
\hline & 75 & 39,21 & 0,079 & 3,09759 \\
\hline \multirow{7}{*}{$\begin{array}{c}\text { Module } \\
8\end{array}$} & 81 & 56,52 & 0,04 & 2,2608 \\
\hline & 82 & 56,76 & 0,038 & 2,15688 \\
\hline & 83 & 76,19 & 0,026 & 1,98094 \\
\hline & 84 & 52,94 & 0,008 & 0,42352 \\
\hline & 85 & 47,16 & 0,014 & 0,66024 \\
\hline & 86 & 40 & 0,064 & 2,56 \\
\hline & 87 & 37,5 & 0,022 & 0,825 \\
\hline \multirow{3}{*}{$\begin{array}{l}\text { Module } \\
9\end{array}$} & 91 & 68,97 & 0,066 & 4,55202 \\
\hline & 92 & 46,3 & 0,088 & 4,0744 \\
\hline & 93 & 44 & 0,059 & 2,596 \\
\hline \multirow{3}{*}{$\begin{array}{l}\text { Module } \\
10\end{array}$} & 101 & 63,17 & 0,008 & 0,50536 \\
\hline & 102 & 50 & 0,058 & 2,9 \\
\hline & 103 & 37,45 & 0,022 & 0,8239 \\
\hline
\end{tabular}

However, in order to find the most effective and efficient way to the organizational excellence, it is necessary to highlight the most important fields in which an organization should enhance ongoing improvement activities.

For this purpose, according to the appropriate approach for subject fields [53-55], Pareto principle, or better say, ABC methodology distribution 70/20/10, was applied.

Accordingly, as fields that have the greatest impact in this sense were selected those shown in Tab. 2 .

For the purposes of development system for decisionmaking support, in addition to these indicators, it is necessary to include indicators that take into account the real operating conditions, and the experience collected during the experimental research. 
Table 2 Fields with the greatest impact for achieving organisational excellence

\begin{tabular}{|c|l|c|}
\hline $\begin{array}{c}\text { Field of } \\
\text { standard }\end{array}$ & \multicolumn{1}{|c|}{ Description } & $\begin{array}{c}S_{Z z} ; \\
z=1,2, \ldots, 11\end{array}$ \\
\hline 51 & Leadership and commitment & 0,053 \\
\hline 52 & Quality policy and dissemination & 0,054 \\
\hline 61 & $\begin{array}{l}\text { Actions to address risks and } \\
\text { opportunities }\end{array}$ & 0,045 \\
\hline 71 & Resources & 0,064 \\
\hline 74 & Communications & 0,056 \\
\hline 75 & Documented information & 0,079 \\
\hline 86 & Release of products and services & 0,064 \\
\hline 91 & $\begin{array}{l}\text { Monitoring, measurement, } \\
\text { analysis and evaluation }\end{array}$ & 0,066 \\
\hline 92 & Internal audit & 0,088 \\
\hline 93 & Management review & 0,059 \\
\hline 102 & $\begin{array}{l}\text { Non-complianceand corrective } \\
\text { action }\end{array}$ & 0,058 \\
\hline
\end{tabular}

These indicators have been identified, by applying the same approach (Tab. 3).

Table 3 Fields with the greatest potential for achieving organisational excellence, taking into account real business conditions

\begin{tabular}{|c|c|c|}
\hline \multicolumn{3}{|c|}{ excellence, taking into account real business conaltions } \\
\hline $\begin{array}{l}\text { Field of } \\
\text { standard }\end{array}$ & Description & $\begin{array}{l}R_{r} \\
r=1,2, \ldots, 11\end{array}$ \\
\hline 51 & Leadership and commitment & 4,41225 \\
\hline 52 & Quality policy and dissemination & 3,78 \\
\hline 71 & Resources & 3,91488 \\
\hline 73 & Awareness & 2,22548 \\
\hline 75 & Documented information & 3,09759 \\
\hline 81 & Planning and control & 2,2608 \\
\hline 86 & Release of products and services & 2,56 \\
\hline 91 & $\begin{array}{l}\text { Monitoring, measurement, } \\
\text { analysis and evaluation }\end{array}$ & 4,55202 \\
\hline 92 & Internal audit & 4,0744 \\
\hline 93 & Management review & 2,596 \\
\hline 102 & $\begin{array}{l}\text { Non-compliance and corrective } \\
\text { action }\end{array}$ & 2,9 \\
\hline
\end{tabular}

Based on these indicators, beside the indication of a priority and an important area for achieving business excellence, and in terms of defining the measures for the improvement are obtained information, which is necessary for the implementation of an expert system. In addition, bearing in mind the importance of the field, as well as the real conditions, priority fields where organizations need to implement additional significant activities in improvement, in order to achieve excellent results, as well as priority important fields for the development of expert systems, can be obtained by applying the following expression:

$$
P=\frac{S_{Z z}}{R_{r}} ; z, r=1,2, \ldots, 11
$$

And they are:

- 61 - Actions to address risks and opportunities $\left(S_{Z}=\right.$ $0,045 ; R=1,07145)$ and

- $\quad 74$ - Communications $\left(S_{Z}=0,056 ; R=2,18792\right)$.

\section{$5 \quad$ DEVELOPMENT OF EXPERT SYSTEMS AS DECISION SUPPORT SYSTEM AND VERIFICATION OF RESULTS}

Based on the previously defined results or indicators that indicate the priority and importance of areas for improvement of the system and organizational performance are entered into the process of creating an expert system. Such system has the role of decision support systems in the direction of improving organizational performance and gain levels of business excellence. The parameters listed in the preceding section have a special role in the definition of an expert system inference mechanism, or with the definition of the degree of measure on the output. In this regard, an additional role is played by the data that are shown in the two unique bases, which are applicable in accordance with the access of CBR. The expert system is of integral character with the specificity, which is made through the sub-systems, which are based on a modular approach. Objects in the expert systems have been developed in accordance with the fields of activity and the indicators are presented in the previous section, which is also important for the definition of the intensity of knowledge representation. The development of facilities in the system depends on the problems and current activities on its solving. Mechanism operates based on known rules, in which are taken into account the values of probabilities, they are functions of the values of SZ and R coefficients or the values of the indicators that are presented in the previous tables, and they are:

IF $\left[(\right.$ State 1$\left.), \mathrm{f}\left(S_{Z}, R\right)\right]$

THEN $\left[\right.$ State $2, \mathrm{P}($ state 2$\left.)=\mathrm{f}\left(S_{Z}, R\right)\right](3)$

ELSE $\left[\right.$ State $3, \mathrm{P}($ state 3$\left.)=\mathrm{f}\left(S_{Z}, R\right)\right]$

After running the application, system, depending on the problem and response, takes the user to the final recommendations for decision-making and to the interface, which represents the knowledge. Data, respectively the knowledge that is depending on the problem in the field of standard, system generating at the exit, preferably relates to the improvement in priority in a significant and critical field of the standard. In addition, it provides specific recommendations or knowledge and for the other fields of importance to achieve best results, according to the corresponding indicators. Thus defined the solution, based on previously presented methodology and approach, is in accordance with the process of drafting software, tested in real conditions, for the purpose of verification of the results. This procedure was conducted in four organizations, one of which was a participant in the competition for the business excellence award. After testing, in accordance with established standards for the quality of the software, this solution is rated as follows:

- In the parts of technical characteristics, implying profit of software, the impact on the organization of work and problems of use, the solution is rated with an grade of 8,9 and

- In the part of ergonomic features, which include the flexibility of existing systems and general ergonomics, the solution was rated with an average grade of 9,3.

These test results, certainly suggest that this solution can bring significant gains not only in the part of the improvement in the field of subject standard, but also in a part of the overall organizational performance.

Fig. 2 shows an inference mechanism of the developed expert system, which functions based on the production rules. 


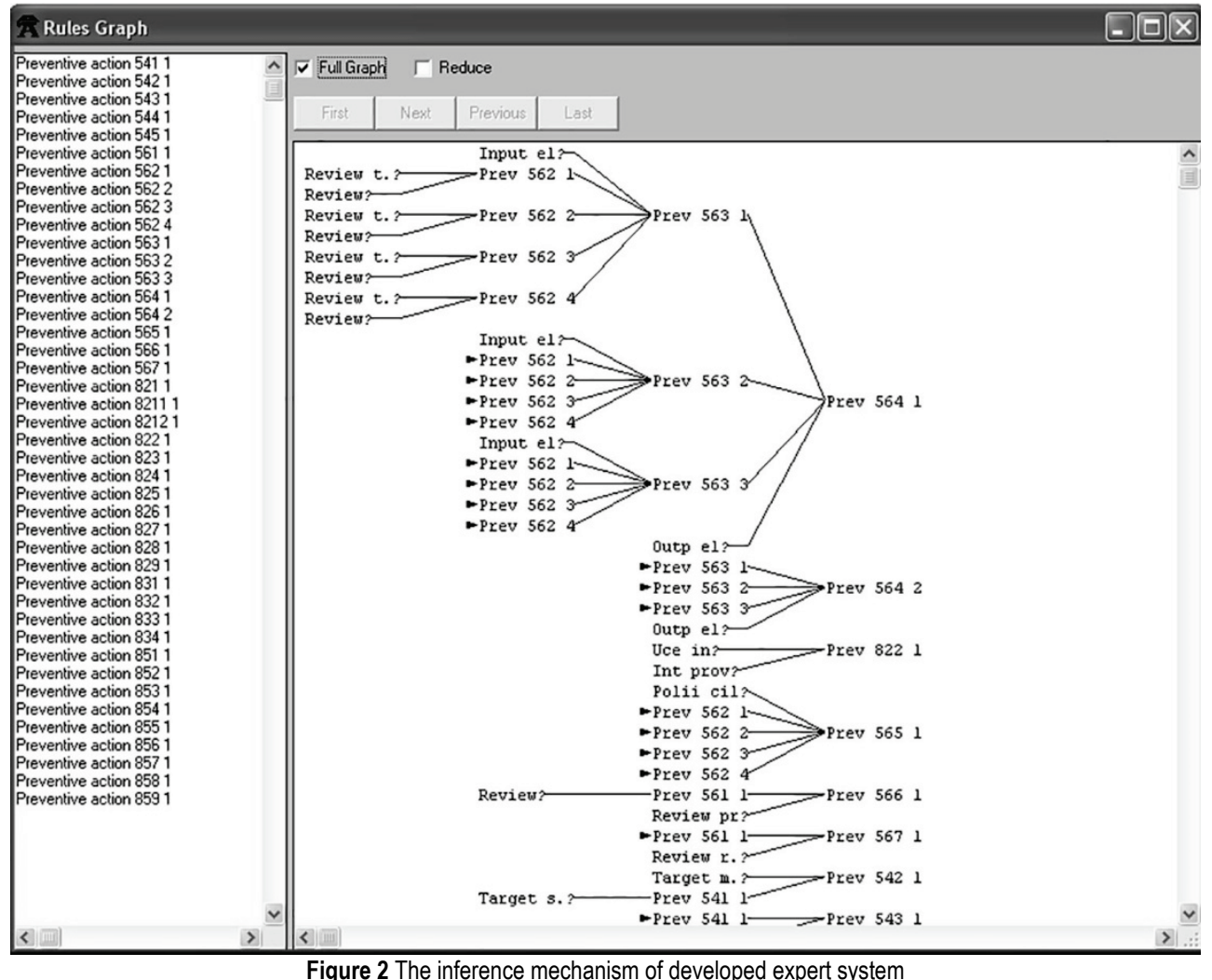

\section{CONCLUSION}

Development of intelligent decision support systems for the improvement of organizational performances is inevitable in terms of ensuring the company's sustainability and competitiveness. Researching the literature sources, it can be concluded that the existing systems and research have partial character and are not comprehensive, and deal with only a small part of the activities or processes in organizations. Also, with an evident lack of available and accessible knowledge, existing systems for reproduction of knowledge depend on the type of organization or their size. After having analyzed the research in the subject field, it can be concluded that correctly implemented QMS has an advantageous effect on the organizational performance. Thus, improvements in this system, leads to the improvement of all organizational performance to those with a financial character. In the paper based on experimental research in a significant number of organizations, is obtained a reference sample for research that is stored in two unique bases encoded data. In this sense, applying the method of the inductive and deductive reasoning, as well as a method of concluding based on experience, expert analysis, logical comparative inferences and multiple criteria decision making method, led to indicators showing the priority fields for improvement (Tab. 2 and Tab. 3), and those which have specifically important or critical level (field 61 - Actions to address risks and opportunities, and field 74 - Communication), which represent the indicators for the development of expert systems, concretely, the inference mechanism and the knowledge base. By application of presented approach, we have obtained the values of the coefficient Rand the values of $S_{Z}$ (Tab. 1), like important indicators for building an expert system.
This approach is certainly not a partial, but a systematic and comprehensive, and also independent of the size or type of organization. By an integrated approach, based on analogy with the relevant functions in the human body, an expert system, like decision support system, have been developed. The function of this system is supporting to decision maker, in order to improving organizational performance, to those of excellent character. This system has a mechanism of inference and the knowledge base which has been developed depending on the value of indicators mentioned above.

The system has been tested in four organizations of which one is with outstanding business results. It was assessed as effective and efficient, with which was carried out and its validation. Finally, a system generate knowledge which has a particularly significant effect on improving and potentiating the development of the communication activities, risk analysis procedures, the development of organizational resources, the development of control mechanisms, supporting of users requirements, but also on other processes in the organization.

\section{REFERENCES}

[1] Zhang, R., Song S., \& Wu, C. (2013). A hybrid artificial bee colony algorithm for the job shop scheduling problem. International Journal of Production Economics, 141(1), 167-178. https://doi.org/10.1016/j.jpe.2012.03.035

[2] Köksal, G., Batmaz, I., \& Testik, M. (2011). A review of data mining applications for quality improvement in manufacturing industry. Expert Systems with Applications $38(10), 13448-13467$. https://doi.org/10.1016/j.eswa.2011.04.063

[3] Hermi, S., Romdhane, T., \& Ketata, R. (2009). Intelligent Model of Continuous Improvement Mechanisms Scope of QMS. Paper presented at the 2009 IEEE International 
Conference on Systems, Man, and Cybernetics, San AntonioUSA. https://doi.org/10.1109/ICSMC.2009.5345992

[4] Özbakir, L., Baykasoğlu, A., \& Tapkan, P. (2010). Bees' algorithm for generalized assignment problem. Applied Mathematics and Computation, 215(11), 3782-3795. https://doi.org/10.1016/j.amc.2009.11.018

[5] Mansouri, P., Asady, B., \& Gupta, N. (2015). The bisectionartificial bee colony algorithm to solve fixed point problems. Applied Soft Computing, 26(1), 143-148 https://doi.org/10.1016/j.asoc.2014.09.001

[6] Kiran, M. S. \& Findik, O. (2015). A directed artificial bee colony algorithm. Applied Soft Computing, 26(1), 454-462. https://doi.org/10.1016/j.asoc.2014.10.020

[7] Banharnsakun, A., Sirinaovakul, B., \& Achalakul, T. (2013). The best-so-far ABC with multiple patrilines for clustering problems. Neurocomputing, 116(1), 355-366. https://doi.org/10.1016/j.neucom.2012.02.047

[8] Dhouib, S. (2015). Improving the ISO 9000 Factual Approach Principle through Metaheuristic. Innovative Systems Design and Engineering, 6(4), 10-15.

[9] Filos, E. (2013). Manufacturing innovation and horizon 2020. Paper presented at the IFIP TC 5 International conference, Dresden - Germany. https://doi.org/10.1007/978-3-642-41329-2_1

[10] Wuest, T., Irgens, C., \& Thoben, K. (2014). An approach to monitoring quality in manufacturing using supervised machine learning on product state data. Journal of Intelligent Manufacturing, 25(5), 1167-1180. https://doi.org/10.1007/s10845-013-0761-y

[11] Asif, M., Searcy, C., Zutshi, A., \& Fisscher, O. (2013). An integrated management systems approach to corporate social responsibility. Journal of Cleaner Production 56(1), 7-17. https://doi.org/10.1016/j.jclepro.2011.10.034

[12] Solomon, J. \& Solomon, A. (2004). Corporate Governance and Accountability. Chichester-West Sussex, England: John Wiley \& Sons, Ltd

[13] Sage, A. P. (2009). Systems engineering and management for sustainable development. Retrieved from https://www.eolss.net/sample-chapters/C15/E1-28.pdf

[14] Amelio Medina, J., De Pablos, C., Jimenez, L., \& Peñas, J. (2011). Application of the Artificial Intelligence in Enterprise Quality Systems - DCAI 2011. Paper presented at the International Symposium on Distributed Computing and Artificial Intelligence, Salamanca, Spain. https://doi.org/10.1007/978-3-642-19934-9_37

[15] Manyika, J., Chui, M., Brown, B., Bughin, J., Dobbs, R., Roxburgh, C., \& Byers, A.H. (2011). Big data: The next frontier for innovation, competition, and productivity. Retrieved from https://bigdatawg.nist.gov/pdf/MGI_big data_full_report.pdf

[16] Russell, S., Dewey, D., \& Tegmark, M. (2015). Research Priorities for Robust and Beneficial Artificial Intelligence. AI Magazine, 36(4). Retrieved from https://futureoflife.org/ data/documents/research_priorities.pdf https://doi.org/10.1609/aimag.v36i4.2577

[17] Mc Cormick, J. (2016). Artificial Intelligence Will Drive The Insights Revolution-Advanced Insights Will Spark Digital Transformation In The Year Ahead. Retrieved from https:/go.forrester.com/wp-content/uploads/Forrester Predictions_2017_-Artificial_Intelligence_Will_Drive_ The_Insights_Revolution.pdf

[18] Yussupova, N., Kovács, G., Boyko, M., \& Bogdanova, D. (2016). Models and Methods for Quality Management Based on Artificial Intelligence Applications. Acta Polytechnica Hungarica, 13(3), 45-60.

[19] Arsovski, Z., Pavlović, A., Arsovski, S., \& Mirović, Z. (2009). Improving the Quality of Maintenance Processes by Using Information Technology. Strojniški vestnik, 55(11), 701-714.
[20] Lukovic, I., Pereira, M. J., Oliveira, N., Cruz, D., \& Henriques, P. R. (2011). A DSL for PIM Specifications: Design and Attribute Grammar based Implementation. Computer Science and Information Systems, 8(2), 379-403. https://doi.org/10.2298/CSIS101229018L

[21] Ghaffarzadeh, S. A. M. (2015). Decision Making Based On Management Information System and Decision Support System. Journal of Management Research and Analysis, January 2(1), 98-107.

[22] Petter, S., DeLone, W., \& McLean, E. (2008). Measuring information systems success: models, dimensions, measures, and interrelationships. European Journal of Information Systems, 17(3), 236-263. https://doi.org/10.1057/ejis.2008.15

[23] Hasan, Y., Mamary, A., Shamsuddin, A., \& Aziaty, N. (2013). The Impact of Management Information Systems Adoption in Managerial Decision Making: A Review. Management Information Systems, 8(4), 010-017.

[24] Nowduri, S. \& Al-Dossary, S. (2012). Management Information Systems and Its Support to Sustainable Small and Medium Enterprises. International Journal of Business and Management, 7(19), 125-131. https://doi.org/10.5539/ijbm.v7n19p125

[25] Jaglan, V., Dalal, S., \& Srinivasan, S. (2011). Improving performance of business intelligence through case based reasoning. International Journal of Engineering Science and Technology, 3(4), 2880-2886

[26] Kendall-Morwick, J., \& Leake, D. (2014). A Study of TwoPhase Retrieval for Process-Oriented Case-Based Reasoning. https://doi.org/10.1007/978-3-642-38736-4_2

[27] Tari, J., Molina-Azorín, J., \& Heras, I. (2012). Benefits of the ISO 9001 and ISO 14001 standards: A literature review. Journal of Industrial Engineering and Management JIEM, 5(2), 297-322. https://doi.org/10.3926/jiem.488

[28] Bell, M. \& Omachonu, V. (2011). Quality system implementation process for business success. International Journal of Quality \& Reliability Management, 28(7), 723734. https://doi.org/10.1108/02656711111150814

[29] Psomas, E., \& Antony, J. (2015). The effectiveness of the ISO 9001 quality management system and its influential critical factors in Greek manufacturing companies. International Journal of Production Research, 53(7), 1-11. https://doi.org/10.1080/00207543.2014.965353

[30] Ratsoeu, E. (2012). The Impact of Quality Assurance Systems on the operational performance of laboratories, Master's thesis. Retrieved from file://C:/Users/User/ Downloads/PDF\%20Document\%20(3).pdf

[31] Karim, A. (2015). ISO Certification and Financial Performance: A Review. The Journal of Global Business Management, 11(2), 32-38.

[32] Chatzoglou, P., Chatzoudes, D., \& Kipraios, N. (2015). The impact of ISO 9000 certification on firms' financial performance. International Journal of Operations \& Production Management, 35(1), 145-174. https://doi.org/10.1108/IJOPM-07-2012-0387

[33] Ismyrlis, V. \& Moschidis, O. (2015). The effects of ISO 9001 certification on the performance of Greek companies. TQM Journal, 27(1), 150-162. https://doi.org/10.1108/TQM-07-2013-0091

[34] Starke, F., Eunni, R., Fouto, N., \& Felisoni de Angelo, C. (2012). Impact of ISO 9000 certification on firm performance: Evidence from Brazil. Management Research Review, 35(10), 974-997. https://doi.org/10.1108/01409171211272697

[35] Manders, B. (2015). Implementation and Impact of ISO 9001, Doctoral dissertation. Retrieved from file://C:/Users/ User/Downloads/EPS2014337LIS9789058923943\%20(5).p df

[36] Santos, G. \& Millán, A. L. (2013). Motivation and benefits of implementation and certification according ISO 9001- the 
Portuguese experience. International Journal for Quality Research, 7(1), 71-86.

[37] Vujovic, A., Jovanovic, J., Krivokapic, Z., Pekovic, S., Sokovic, M., \& Kramar, D. (2017). The relationship between innovations and quality management system. Technical gazette, 24(2), 551-556. https://doi.org/10.17559/TV-20150528100824

[38] Abraham, M., Crawford, J., Carter, D., \& Mazotta, F. (2000). Management decisions for effective ISO 9000 accreditation. Management Decision. 38(3), 182-193. https://doi.org/10.1108/EUM0000000005346

[39] Eccles, R. \& Pyburn, P. (1992). Creating a comprehensive performance measuring system. Management Accounting, 74(4), 41-44

[40] Rusjan, B. \& Alič, M. (2010). Capitalising on ISO 9001 benefits for strategic results. International Journal of Quality and Reliability Management, 27(7), 756-778. https://doi.org/10.1108/02656711011062372

[41] Miguel Fonseca, L., \& Marlene Lima, V. (2015). Impact of Supplier Management Strategies on the Organizational Performance of ISO 9001 Certified Organizations. Quality innovation prosperity, 19(2), 32-54. https://doi.org/10.12776/qip.v19i2.592

[42] Prajogo, D., Huo, B., \& Han, Z. (2012). The effects of different aspects of ISO 9000 implementation on key supply chain management practices and operational performance. Supply Chain Management: An International Journal, 17(3), 306-322. https://doi.org/10.1108/13598541211227135

[43] Croft, N. H. (2012). ISO 9001:2015 and beyond - Preparing for the next 25 years of quality management standards. Retrieved from https://www.iso.org/news/2012/08/ Ref1633.html

[44] Singh, J., Power, D., \& Chuong, S. C. (2011). A resource dependence theory perspective of ISO 9000 in managing organizational environment. Journal of Operations Management, 29(1-2), 49-64. https://doi.org/10.1016/j.jom.2010.04.002

[45] Hartnell, A., Ou, Y., \& Kinicki, A. (2011). Organizational culture and organizational effectiveness: A meta-analytic investigation of the competing values framework's theoretical suppositions. Journal of Applied Psychology, 96(4), 677-694. https://doi.org/10.1037/a0021987

[46] Sackmann, A., Eggenhofer-Rehart, P., \& Friesl, M. (2009). Sustainable change: Long-term efforts toward developing a learning organization. Journal of Applied Behavioral Science, 45(4), 521-549. https://doi.org/10.1177/0021886309346001

[47] Terziovski, M. \& Guerrero, J. (2014). ISO 9000 quality system certification and its impact on product and process innovation performance. International Journal of Production Economics, 158(1), 197-207. https://doi.org/10.1016/j.jpe.2014.08.011

[48] Wiengarten, F., Humphreys, P., Onofrei, G., \& Fynes, B. (2016). The adoption of multiple certification standards: perceived performance implications of quality, environmental and health \& safety certifications. Journal Production Planning \& Control the Management of Operations, 28(2), 131-141. https://doi.org/10.1080/09537287.2016.1239847

[49] Parast, M., Adams, S., \& Jones, E. (2011). Improving Operational and Business Performance in the Petroleum Industry through Quality Management. International Journal of Quality \& Reliability Management, 28(4), 426450. https://doi.org/10.1108/02656711111121825

[50] Shahin, A. \& Dabestani, R. (2011). A feasibility study of the implementation of total quality management based on soft factor. Journal of Industrial Engineering and Management, 4(2), 258-280. https://doi.org/10.3926/jiem.2011.v4n2.p258-280
[51] Stanković, S. (2006). Fizika ljudskog organizma. Retrieved from www.kelm.ftn.uns.ac.rs/literatura/fljo/fljo_predavanje 2 deo.pdf

[52] Gilja, I. (2005). Prostate urinary incontinence. Medix, 11(60/61), 119-120.

[53] Eslaminasab, Z. \& Dokoohaki, T. (2012). ABC inventory classification with multiple-criteria using weighted nonlinear programming. Paper present at the First Regional Conference on the Advanced Mathematics and Its Applications, Mobarakeh, Iran. https://doi.org/10.5899/2012/cjac-001-028

[54] Shil, N. C. \& Das, B. (2012). Right product pricing: Application of activity-based costing (ABC)-and- economic value added (EVA) as an integrated tool. Journal of Business Management, 6(44), 10826-10833.

[55] Jatta, J. S. (2016). Supply chain planning and control: an examination of demand planning and inventory classification, Doctoral dissertation. Retrieved from https://soar.wichita.edu/bitstream/handle/10057/13511/d16 046_Jatta.pdf? sequence $=1$

\section{Contact information:}

Aleksandar VUJOVIC, PhD, Associate Professor (Corresponding author)

University of Montenegro, Faculty of Mechanical Engineering,

Džordža Vašingtona bb, 81000 Podgorica, Montenegro

E-mail: aleksv@ac.me

\section{Zdravko KRIVOKAPIC, PhD, Full Professor}

University of Montenegro, Faculty of Mechanical Engineering,

Džordža Vašingtona bb, 81000 Podgorica, Montenegro

E-mail: zdravkok@ac.me

Miladin STEFANOVIC, PhD, Full Professor

University of Kragujevac, Faculty of Engineering Science,

Sestre Janjic 6, 34000 Kragujevac, Serbia

E-mail: miladin@kg.ac.rs

Jelena JOVANOVIC, PhD, Associate Professor

University of Montenegro, Faculty of Mechanical Engineering,

Džordža Vašingtona bb, 81000 Podgorica, Montenegro

E-mail: sjelena@t-com.me 